\title{
EFEKTIFITAS PEMBELAJARAN MATEMATIKA MELALUI MODEL PEMBELAJARAN REALISTIC MATEMATIC EDUCATION (RME) TERHADAP PENINGKATAN PEMAHAMAN KONSEP MATEMATIKA SISWA SD
}

\author{
Achmad (achmad@ut.ac.id) \\ Irmansyah \\ Universitas Terbuka
}

\begin{abstract}
The research purpose was to describe the successfulness of Realistic Mathematic Education Model which was based on the completion aspect of students' learning result, students' activity level, teacher's ability to manage learning, and students' response toward the model applied in this research. This research was conducted toward the third year students of SD Islam Terpadu which consist of 25 students. In gathering data, pen and paper test technique was used to measure students' achievement. Observation was done to know students' activities and teacher's ability in manage learning.Questioner was also given to know the students' perceptions toward the model applied. Statistic and descriptive analysis were used to analyze the data. The research finding showed that the students' activities were not effective, while the teacher's ability in managing learning was effective. In the end, standard for students' achievement were not reached. On the other hand, students' responses toward the model applied were positive.
\end{abstract}

Keywords: Realistic Mathematic Education, students' perception

Masalah pendidikan matematika selalu menjadi sorotan, karena masih rendahnya prestasi belajar siswa pada bidang studi tersebut. Usaha untuk meningkatkan mutu pendidikan matematika di Indonesia telah lama dilaksanakan, namun keluhan tentang kesulitan belajar matematika masih saja terus dijumpai.

Rendahnya hasil belajar siswa dalam pembelajaran matematika bukan semata-mata karena materi yang sulit, tetapi bisa juga disebabkan oleh proses pembelajaran yang dilaksanakan. Betapapun tepat dan baiknya bahan ajar matematika yang diberikan belumlah menjamin akan tercapainya tujuan pendidikan matematika yang diinginkan. Salah satu faktor penting untuk mencapai tujuan pendidikan adalah proses belajar yang dilaksanakan (Sudjadi,2001a). Kenyataan di lapangan menunjukkan bahwa pembelajaran matematika pada umumnya masih terpusat pada guru, bukan pada siswa.

Dalam pengajaran matematika guru cenderung mentransfer pengetahuan yang mereka miliki ke dalam pikiran siswa. Siswa sering diposisikan sebagai orang yang "tidak tahu apa-apa" yang hanya menunggu apa yang guru berikan (Ratumanan, 2000). Dalam kurikulum matematika sekolah di Indonesia dan dalam pembelajarannya selama ini terpateri kebiasaan dengan urutan sajian pembelajaran sebagai berikut: (1) diajarkan teori/ teorema/definisi (2) diberikan contoh-contoh dan (3) diberikan latihan soal-soal. (Soedjadi, 2001a). Kebiasaan pembelajaran semacam ini menyebabkan guru mendominasi kegiatan belajar mengajar, sementara siswa hanya menjadi pendengar dan pencatat yang baik. Hasilnya adalah siswa yang kurang mandiri, tidak berani 
mengemukakan pendapat sendiri, selalu meminta bimbingan guru, dan kurang gigih melakukan ujicoba dalam menyelesaikan masalah matematika, sehingga pengetahuan yang dipahami siswa hanya sebatas apa yang diberikan guru. Dalam proses pembelajaran guru hendaknya memberikan arahan kepada siswa tentang bagaimana siswa harus belajar. Seperti yang diungkapkan oleh Weinstein dan Meyer (dalam Arends, 1997) bahwa: "good teaching includes teaching students how to learn, how to remember, how to think, and how to motivate themselves".

Peran guru dalam kegiatan belajar mengajar adalah sebagai fasilitator dan motivator untuk mengoptimalkan belajar siswa. Ratumanan (2000) menyarankan agar guru berpandangan bahwa matematika merupakan proses, sehingga pengajaran matematika merupakan suatu usaha membantu siswa untuk mengkonstruksi pengetahuan dengan kemampuannya sendiri melalui proses internalisasi sehingga pengetahuan tersebut terkonstruksi kembali.

Dalam pandangan konstruktivis, mengajar bukanlah meneruskan pengetahuan dari kepala guru ke kepada siswa, tetapi mengajar adalah proses negosiasi makna. Guru lebih banyak berperan sebagai fasilitator dan mediator yang kreatif, sedangkan siswa dipandang sebagai bagian yang aktif dan bertanggung jawab atas pembelajarannya sendiri. Salah satu ciri lingkungan belajar yang beraliran konstruktivis adalah jika dalam mengajar guru mengintegrasikan pembelajaran dengan situasi yang realistis dan relevan serta melibatkan siswa baik secara emosional maupun sosial agar pembelajaran matematika menjadi menarik dan menyenangkan (Hudoyo, 1998). Selanjutnya Burril (1997) mengemukakan bahwa: Good teaching is not making learning easy!, is not making hard either. Students, teachers, parents, and administrators should understand that good teaching means that students are actively engaged in the learning process. Students are involved with problems, they struggle with ideas, and they take part in the dialogue".

Model pembelajaran Realistic Mathematics Education (RME) merupakan salah satu alternatif pembelajaran yang menuntut siswa untuk mengkonstruksi pengetahuan dengan kemampuannya sendiri melalui aktivitas yang dilakukannya dalam kegiatan pembelajaran. Ide utama pembelajaran dengan menggunakan model pembelajaran RME adalah siswa harus diberi kesempatan untuk menemukan kembali (reinventing) konsep matematika dengan bimbingan orang dewasa (Gravemeijer, 1994). Prinsip menemukan kembali berarti siswa diberi kesempatan menemukan sendiri konsep matematika dengan menyelesaikan berbagai soal kontekstual yang diberikan pada awal pembelajaran.

Berdasarkan soal, siswa membangun model berdasarkan situasi kemudian menyelesaikan hingga mendapatkan pengetahuan formal matematika (Gravemeijer, 1994). Selain itu dalam pandangan ini, matematika dipandang sebagai suatu kegiatan manusia sehari-hari. Oleh karena itu pembelajaran matematika harus dikaitkan dan menjadi bagian dari kegiatan manusia sehari-hari (Gravemeijer, 1994).

Upaya untuk menemukan kembali ide dan konsep matematika ini dilakukan dengan memanfaatkan realita dan lingkungan yang dekat dengan anak. Soedjadi (2001a) mengemukakan bahwa pembelajaran matematika realistik pada dasarnya adalah pemanfaatan realita dan lingkungan yang dipahami peserta didik untuk memperlancar proses pembelajaran matematika sehingga mencapai tujuan pendidikan matematika secara lebih baik daripada masa yang lalu. Lebih lanjut Soedjadi (2001a) menjelaskan yang dimaksud dengan realita yaitu hal-hal yang nyata atau konkrit yang dapat diamati atau dipahami peserta didik lewat membayangkan, sedangkan yang dimaksud dengan lingkungan adalah lingkungan tempat peserta didik berada baik lingkungan sekolah, keluarga maupun masyarakat yang dapat dipahami peserta didik. 
Model Pembelajaran RME telah dikembangkan di Belanda selama kurang lebih 30 tahun, dan menunjukkan hasil yang baik. RME juga dikembangkan di beberapa negara lain seperti USA (yang dikenal dengan Mathematics in Context), Afrika Selatan, Malaysia, Inggris, Brazil, dan lain-lain (Fauzan, 2001). Laporan dari TIMMS (Third International Mathematics and Science Study) menyebutkan bahwa berdasarkan penilaian TIMSS, siswa di Belanda memperoleh hasil yang memuaskan baik dalam ketrampilan komputasi maupun kemampuan pemecahan masalah (dalam Yuwono, 2001).

Belajar matematika merupakan kegiatan mental yang tinggi karena matematika berkenaan dengan ide-ide abstrak yang diberi simbol-simbol yang tersusun secara hirarkis dan penalarannya deduktif (Hudojo, 1988). Belajar matematika pada hakikatnya adalah belajar berkenaan dengan ideide, struktur-struktur yang diatur menurut urutan yang logis.

Proses pembelajaran matematika dengan RME menggunakan masalah kontekstual (contextual problems) sebagai titik awal dalam belajar matematika. Dalam hal ini siswa melakukan aktivitas matematisasi horisontal, yaitu siswa mengorganisasikan masalah dan mencoba mengidentifikasi aspek matematika yang ada pada masalah tersebut. Siswa bebas mendeskripsikan, menginterpretasikan dan menyelesaikan masalah kontekstual dengan caranya sendiri berdasarkan pengetahuan awal yang dimiliki. Kemudian siswa dengan bantuan atau tanpa bantuan guru, menggunakan matematisasi vertikal (melalui abstraksi maupun formalisasi) tiba pada tahap pembentukan konsep. Setelah dicapai pembentukan konsep, siswa dapat mengaplikasikan konsepkonsep matematika tersebut kembali pada masalah kontekstual, sehingga memperkuat pemahaman konsep.

Gravemeijer (1994) mengemukakan bahwa terdapat tiga prinsip kunci dalam model pembelajaran RME yaitu (a) Petunjuk menemukan kembali/matematisasi progresif (guided reinvention/progessive mathematizing), (b) Fenomena yang bersifat mendidik (didactical phenomenology), (c) Mengembangkan model sendiri (Self developed models). Dalam menyelesaikan masalah kontekstual, siswa diberi kesempatan untuk mengembangkan model mereka sendiri, sehingga dimungkinkan muncul berbagai model buatan siswa. Model-model tersebut diharapkan akan berubah dan mengarah kepada bentuk yang lebih baik menuju ke arah pengetahuan matematika formal, sehingga diharapkan terjadi urutan pembelajaran seperti berikut "masalah kontekstual" $\rightarrow$ "model dari masalah kontekstual tersebut" $\rightarrow$ "model ke arah formal" $\rightarrow$ "pengetahuan formal" (Soedjadi, 2001b).

Berdasarkan prinsip dan karakteristik model pembelajaran RME maka yang menjadi cirri-ciri dari model pembelajaran ini adalah sebagai berikut (Nur, 2000).

1. Pembelajaran dirancang berawal dari pemecahan masalah yang ada di sekitar siswa dan berbasis pada pengalaman yang telah dimiliki siswa.

2. Urutan pembelajaran haruslah menghadirkan suatu aktivitas atau eksplorasi.

3. Pembelajaran matematika tidak semata-mata memberi penekanan pada komputasi dan hanya mementingkan langkah-langkah prosedural serta keterampilan, melainkan penekanan pada pemahaman konsep dan pemecahan masalah.

4. Siswa mengalami proses pembelajaran secara bermakna dan memahami matematika dengan penalaran.

5. Siswa belajar matematika dengan pemahaman secara aktif membangun pengetahuan baru dari pengalaman dan pengetahuan awal. 
6. Dalam pembelajaran siswa dilatih untuk megikuti pola kerja, intuisi - coba - salah dugaan/spekulasi - hasil.

7. Terdapat interaksi yang kuat antara siswa yang satu dengan siswa lainnya.

8. Memberikan perhatian yang seimbang antara matematisasi horizontal dan matematisasi vertikal.

Secara umum tujuan penelitian adalah untuk mengetahui efektifitas penerapan model pembelajaran RME dalam pembelajaran matematika. Secara khusus tujuan penelitian ini adalah untuk mendeskripsikan: (a) Kemampuan guru dalam mengelola pembelajaran RME, (b) Respon siswa terhadap model pembelajaran RME, (c) pencapaian ketuntasan belajar siswa yang belajar dengan RME.

Melalui penelitian ini, diharapkan bahwa informasi efektivitas pembelajaran matematika dengan menggunakan model pembelajaran RME dapat dijadikan sebagai suatu alternatif pembelajaran matematika, dalam rangka meningkatkan mutu pendidikan matematika melalui peningkatan aktivitas siswa dan minat siswa dalam belajar.

\section{METODOLOGI}

Subyek penelitian ini adalah siswa kelas 4 SD Islam Terpadu Kota Pontianak yang berjumlah 25 siswa. Prosedur penelitian ini terdiri dari: (a) tahap persiapan yakni mengembangkan perangkat pembelajaran dan instrumen penelitian dan melakukan ujicoba perangkat pembelajaran dan instrument, (b) tahap pelaksanaan yakni memberikan pre-test, melaksanakan pembelajaran RME, memberikan post-test, mengobservasi kemampuan guru dan kegiatan pembelajaran secara keseluruhan, dan memberikan angket kepada siswa tentang persepsi mereka, (c) tahap analisis data yaitu menganalisis data pre-test dan post-test, menganalisis data kemampuan guru, dan menganalisis data angket. Selanjutnya pelaporan hasil dilakukan secara deskriptif.

\section{HASIL DAN PEMBAHASAN}

Hasil penelitian ini terdiri dari deskripsi kemampuan guru mengelola pembelajaran dengan RME, deskripsi respon siswa terhadap pembelajaran RME dan deskripsi ketuntasan belajar siswa yang mengikuti pembelajaran RME dalam kerangka pembelajaran tatap muka.

\section{Deskripsi Kemampuan Guru Mengelola Pembelajaran Matematika Metode RME}

Tabel 1 menunjukkan hasil perhitungan rata-rata kemampuan guru mengelola pembelajaran mulai dari tahap pendahuluan, tahap kegiatan inti sampai tahap mengakhiri pembelajaran, sebanyak 4 pertemuan. Data kemampuan guru mengelola pembelajaran dianalisis dengan menghitung ratarata setiap aspek yang diamati dalam mengelola pembelajaran dari empat kali pertemuan.

Selanjutnya nilai rata-rata tersebut dikonversikan dengan kriteria: nilai 1,00-1,49= tidak baik; nilai 1,50-2,49 = kurang baik; nilai 2,50-3,49 = baik; dan nilai 3,50-4,00 = sangat baik. Kemampuan guru mengelola pembelajaran dikatakan efektif, bila rata-rata nilai setiap aspek yang diamati dalam mengelola pembelajaran dari empat kali pertemuan termasuk kategori baik atau sangat baik.

Dari tabel 1 terlihat bahwa rata-rata nilai setiap aspek yang diamati dalam mengelola pembelajaran dari empat kali pertemuan termasuk dalam kategori baik atau sangat baik. Hal ini menunjukkan bahwa guru dalam mengelola pembelajaran RME tergolong efektif. 
Tabel 1. Kemampuan Guru dalam Mengelola Pembelajaran RME

\begin{tabular}{lllll} 
Kategori Pengamatan & \multicolumn{3}{c}{ Pertemuan ke - } & $\begin{array}{l}\text { Rata- } \\
\text { rata }\end{array}$
\end{tabular}

Pendahuluan

$\begin{array}{llllllll}\text { 1. Memotivasi/ mengkomunika- } & 1 & 3 & 3 & 4 & 2,5 & \text { Baik }\end{array}$ sikan tujuan pembelajaran

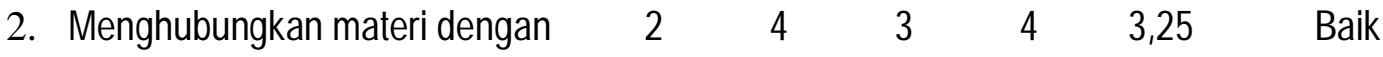
materi sebelumnya

Kegiatan inti

$\begin{array}{lllllll}\text { 1. Memberikan masalah kon- } & 3 & 3 & 4 & 3 & 3,25 & \text { Baik }\end{array}$ tekstual.

$\begin{array}{lllllll}\text { 2. Mengarahkan siswa untuk } & 2 & 3 & 2 & 3 & 2,5 & \text { Baik }\end{array}$ menemukan dan cara menjawab soal dengan memberi petunjuk seperlunya.

3. Mengamati cara siswa menyelesaikan masalah secara bergiliran

4. Mendorong siswa untuk membandingkan jawaban antar siswa dalam kelompok

5. Mendorong siswa untuk mengemukakan ide atau menanggapi ide siswa lain dalam diskusi kelas.

5. Menghargai berbagai penda-pat. $\quad \begin{array}{lllllll}3 & 3 & 3 & 3 & 3 & \text { Baik }\end{array}$

6. Mengendalikan negoisasi

7. Mengarahkan siswa untuk menarik kesimpulan suatu prosedur / konsep.

8. Memberikan kesempatan kepada siswa untuk bertanya dan menjawab pertanyaan siswa

$\begin{array}{llllll}3 & 3 & 3 & 4 & 3,25 & \text { Baik }\end{array}$

$\begin{array}{llllll}2 & 2 & 3 & 3 & 2,5 & \text { Baik }\end{array}$

$\begin{array}{llllll}3 & 3 & 3 & 3 & 3 & \text { Baik }\end{array}$

Penutup

1. Menegaskan kembali kesimpulan materi.

2. Memberikan tugas rumah

Pengelolaan Waktu

$\begin{array}{llllll}2 & 3 & 2 & 3 & 2,5 & \text { Baik }\end{array}$

Suasana Kelas

1. Antusias siswa

2

$4 \quad 3,5$

Sangat Baik

2. Antusias guru

\begin{tabular}{cccccc}
4 & 4 & 4 & 4 & 4 & $\begin{array}{c}\text { Sangat Baik } \\
4\end{array}$ \\
3 & 4 & 4 & 4 & 4 & $\begin{array}{c}\text { Sangat Baik } \\
\text { Baik }\end{array}$ \\
3 & 3 & 3 & 3 & 2,75 & Baik \\
3 & 3 & 3 & 4 & 3,25 & Baik \\
\hline
\end{tabular}




\section{Deskripsi Respon Siswa terhadap Pembelajaran}

Dalam beberapa pustaka telah disebutkan bahwa pembelajaran matematika dengan metode RME akan lebih menarik dibandingkan dengan metode ekspositori yang biasa dilakukan. Untuk itu perlu diketahui bagaimana pendapat siswa terhadap metode ini. Tabel 2 menunjukkan tanggapan atau pendapat siswa terhadap pembelajaran cara RMEyang dikelompokkan dalam kategori senang dan tidak senang terhadap komponen mengajar yang terkait dengan materi, buku siswa, suasana belajar di kelas, dan cara guru mengajar. Dari Tabel 2 tersebut ternyata sebagian besar siswa (72\% sampai 100\%) senang dengan cara pembelajaran RME.

Tabel 2. Pendapat Siswa Terhadap Cara Pembelajaran RME atas Beberapa Komponen Pembelajaran

\begin{tabular}{lcc}
\hline \multicolumn{1}{c}{ Komponen pembelajaran } & Senang & Tidak senang \\
\hline Materi pelajaran & $96 \%$ & $4 \%$ \\
Buku siswa & $100 \%$ & $0 \%$ \\
Suasana belajar di kelas & $72 \%$ & $28 \%$ \\
Cara guru mengajar & $100 \%$ & $0 \%$ \\
\hline
\end{tabular}

Dalam penelitian ini siswa juga ditanya apakah metode pembelajaran RME tersebut menurut mereka tergolong baru atau tidak baru. Hasilnya tertera pada Tabel 3. Ternyata sebagian besar siswa menganggap pendekatan pembelajaran tersebut adalah baru bagi mereka. Terbukti bahwa selama ini sebagian besar siswa belum mengenal cara pembelajaran matematika dengan RME.

Tabel 3. Pendapat Siswa Terhadap Kebaruan dari Komponen Pembelajaran RME

\begin{tabular}{lcc}
\hline \multicolumn{1}{c}{ Keterangan } & Baru & Tidak baru \\
\hline Materi pelajaran & $84 \%$ & $16 \%$ \\
Buku siswa & $88 \%$ & $12 \%$ \\
Suasana belajar di kelas & $68 \%$ & $32 \%$ \\
Cara guru mengajar & $96 \%$ & $4 \%$ \\
\hline
\end{tabular}

Berkaitan dengan prospek pembelajaran RME selanjutnya, tampaknya ditanggapi dengan positip oleh siswa. Ketika ditanyakan apakah siswa berminat mengikuti kegiatan belajar berikutnya seperti yang telah diikuti sekarang ini, yaitu dengan metode RME, 84\% siswa menjawab berminat. Sisanya (16\%) menjawab tidak berminat. Walaupun yang tidak berminat relatif sedikit, namun hal ini juga perlu menjadi perhatian dan pertimbangan bagi guru kelas, karena ternyata tidak semua siswa memiliki gaya belajar dan preferensi yang sama.

Pembelajaran matematika dengan metode RME juga menggunakan buku siswa yang dirancang secara khusus sebelumnya. Berkaitan dengan buku siswa tersebut, dicari tahu pula pendapat siswa terhadap buku ini mengenai bahasa yang digunakan dan penampilan buku secara umum. Hasilnya tertera pada Tabel 4. Ternyata buku siswa juga mendapat respons yang positif. Sebagian besar siswa dapat memahami bahasa yang digunakan (96\%), dan sebagian besar pula tertarik pada penampilan buku siswa tersebut (84\%). 
Tabel 4. Komentar Siswa Terhadap Keterbacaan dan Penampilan Buku Siswa

\begin{tabular}{lcc}
\hline \multicolumn{1}{c}{ Keterangan } & Ya & Tidak \\
\hline a. Apakah kamu dapat memahami bahasa yang & $96 \%$ & $4 \%$ \\
$\begin{array}{l}\text { digunakan dalam buku siswa? } \\
\text { b. Apakah kamu tertarik pada penampilan (tulisan, } \\
\text { gambarnya, letak gambarnya) yang terdapat pada } \\
\text { buku siswa }\end{array}$ & $84 \%$ & $16 \%$ \\
\hline
\end{tabular}

\section{Ketuntasan belajar siswa}

Setelah mendapatkan pembelajaran matematika dengan metode RME maka perbandingan nilai pre-test dan post-test adalah sebagaimana tertera pada Tabel 5. Dengan pembelajaran RME terjadi kenaikan skor rata-rata siswa dari 11,12 menjadi 19,12 dari skor maksimum 30. Jumlah siswa yang tuntas belajar juga meningkat dari 8 orang menjadi 33 orang, dari keseluruhan 44 orang siswa.

Dilihat dari tes hasil belajar, seperti yang tercantum pada Tabel 5, persentase ketuntasan hasil belajar setelah diberikan pembelajaran MRE adalah 75\%. Hal ini menunjukkan bahwa pembelajaran ini belum mencapai ketuntasan klasikal. Menurut observasi, ada beberapa hal yang menyebabkan ketidak tercapaian ketuntasan belajar. Antara lain guru belum bisa mengakomodasi dan mengarahkan pendapat siswa yang berbeda-beda. Pada hal dalam pembelajaran RME diperlukan kreativitas dan kemampuan guru dalam kegiatan tersebut. Selain itu, ketika siswa mengerjakan tugas guru sering memberikan petunjuk yang terlalu berlebihan, sehingga kreativitas siswa dalam mengerjakan tugas dengan caranya sendiri, terbatas dan tidak berkembang.Walaupun ketuntasan secara klasikal tidak tercapai, namun jika dilihat dari ketuntasan sebelum diterapkan model pembelajaran RME telah terjadi kenaikan ketuntasan belajar sebesar $57 \%$ menurut pendapat guru yang diobservasi.

Tabel 5.Tes Hasil Belajar

\begin{tabular}{|c|c|c|}
\hline & PRETES & POSTES \\
\hline Rata-rata skor (skor maximal 30) & 11,12 & 19,12 \\
\hline Jumlah siswa yang tuntas (dari 44 orang siswa) & 8 & 33 \\
\hline Persentase Ketuntasan & $18 \%$ & $75 \%$ \\
\hline
\end{tabular}

Untuk mendeskripsikan ketuntasan belajar siswa digunakan nacuan KKM yang termuat dalam KTSP tahun 2008. Seorang siswa dinyatakan tuntas belajar apabila memiliki daya serap >65\% .Ketuntasan klasikal tercapai apabila > 85\% siswa pada suatu kelas tuntas belajar (Depdiknas 2008).

\section{KESIMPULAN DAN SARAN}

Dari hasil penelitian deskriptif tentang pembelajaran matematika dengan metode RME dapat disimpulkan hal-hal sebagai berikut.

1. Guru yang diteliti ternyata telah memiliki kemampuan yang cukup untuk melakukan pembelajaran matematika dengan metode RME. Guru juga telah dapat melaksanakan pembelajaran tersebut secara efektif.

2. Respons siswa terhadap pembelajaran matematika RME adalah positif. Sebagian besar siswa senang dengan metode tersebut, dan sebagian besar pula menganggap sebagai hal yang baru. 
3. Berkaitan dengan ketuntasan belajar, walaupun terjadi peningkatan hasil belajar, namun menurut standar yang berlaku ketuntasan belajar siswa belum tercapai.

Secara umum, penelitian yang lebih mendalam masih perlu untuk dilakukan guna mencari tahu faktor-faktor lain yang mempengaruhi dan menyebabkan ketidaktuntasan belajar tersebut. Selain itu perlu pula dilakukan perbandingan hasil belajar dengan RME dan dengan metode ekspositori biasa. Dengan demikian informasi yang lebih mendalam dapat diketahui dalam upaya meningkatkan kualitas pembelajaran matematika di dalam kelas secara umum.

\section{REFERENSI}

Arends, R.I. (1997). Classroom instruction and management. New York: Mc Graw-Hill Companies. Burril, G. (1997). President's report: Choice and challenges. Journal for research in mathematics education, V. 28(3), tahun 1997.

Fauzan, A. (2001). Pengembangan dan implementasi prototipe I \& II perangkat pembelajaran geometri untuk siswa kelas 4 SD menggunakan pendekatan realistik. Makalah disajikan pada seminar nasional realistic mathematics education (RME) di jurusan matematika FMIPA UNESA tanggal 24 Februari 2001.

Gravemeijer, K. (1994). Developing realistic mathematics education. Ultrecht: Freudenthal Institute. Hudojo, H. (1988). Mengajar belajar matematika. Jakarta: P2LPTK, Dirjen Dikti, Depdikbud.

Nur, M. (2000). Realistic mathematics education. Pusat penelitian matematika dan sains UNESA Surabaya.

Ratumanan, T.G. (2000). Pengajaran interaktif: Arah baru dalam pengajaran matematika. Dimuat dalam prosiding seminar nasional matematika ITS, 2 November 2000.

Soedjadi, R. (2001a). Pembelajaran matematika. Makalah disajikan pada seminar nasional realistic mathematics education (RME) di jurusan matematika FMIPA UNESA tanggal 24 Februari 2001.

Soedjadi, R. (2001b). Pembelajaran matematika realistik; pengenalan awal dan praktis. Makalah disajikan pada workshop pengembangan pembelajaran RME untuk SD di PPPG matematika Yogyakarta tanggal 4 -11 Juli 2001.

Yuwono, I.(2001). RME (Realistic Mathematics Education) dan hasil studi awal implementasinya di SLTP. Makalah disajikan pada seminar nasional realistic mathematics education (RME) di jurusan matematika FMIPA UNESA tanggal 24 Februari 2001. 